\section{Selcuk Journal of Agriculture and Food Sciences}

http://sjafs.selcuk.edu.tr/sjafs/index

Research Article
SJAFS

(2019) 33 (3), 204-214

e-ISSN: $2458-8377$

DOI:10.15316/SJAFS.2019.177

\title{
Forecasting of Rice Self-Sufficiency in the Benin Republic Using ARIMA Model
}

\author{
Oscar AKOUEGNONHOU ${ }^{1}$, Nevin DEMIRBAŞ ${ }^{2}$ \\ ${ }^{1}$ Ege University, Institute of Science, Department of Agricultural Economics, İzmir, Turkey \\ ${ }^{2}$ Ege University, Faculty of Agriculture, Department of Agricultural Economics, İzmir, Turkey
}

\begin{tabular}{l}
\hline ARTICLE INFO \\
\hline Article history: \\
Received date: 20.05 .2019 \\
Accepted date: 06.08 .2019 \\
\hline Edited by: \\
Zuhal KARAKAYACI; Selçuk \\
University, Turkey \\
Reviewed by: \\
Osman Orkan ÖZER; Adnan Menderes \\
University, Turkey \\
Hary HAYRADİ; Ahmad Dahlan \\
University, Indonesia \\
\hline
\end{tabular}

Keywords:

ARIMA model

İmportation

Riceproduction

Riceconsumption

Self-sufficiency

Benin Republic

\section{Introduction}

In most African countries, the agricultural sector occupies an essential place in the national economy. In Africa, every $1 \%$ increase in agricultural productivity reduces poverty by $0.6 \%$, and a $1 \%$ increase in production reduces the number of people living with less than one dollar a day by 6 million (Thirtle et al. 2003). Two out of five people in Africa still live in extreme poverty (Beegle et al. 2016) and increasing agricultural productivity is crucial for reducing poverty (Christiaensen et al. 2011). Agriculture is the primary production activity of rural livelihoods in subSaharan Africa, and on average $92 \%$ of rural households is engaged in farming (Davis et al. 2017). Rural

Households also derive about two-thirds of their income from on-farm agriculture, compared with onethird (on average) in other developing countries (Christiaensen, 2017).

As a result, the economic "take-off" of SubSaharan African countries in general and of Benin, in

\footnotetext{
* Corresponding author email: akbiggest@ gmail.com
}

particular, is closely linked to agriculture (Aho and Kossou, 1997). The agricultural sector contributes $38 \%$ to Gross Domestic Product (GDP) in Benin (PNUD-IDH, 2011). Crop production is the primary production activity in the agricultural sector and on average contributes $23 \%$ to GDP (FAO, 2012a).

In the crop production sub-sector, cereal products hold the prominent place, and among cereals, corn, sorghum, and rice are the most important ones. Local rice production provides $1 \%$ contribution to GDP (MAEP, 2007). In order to satisfy domestic consumption and re-exportation, Benin imports huge quantities of rice. West Africa is experiencing rapid growth in rice consumption due to population growth, urbanization and increasing purchasing power (Fofana et al. 2014). At the same time, rice is the most critical nutritional source and a highly strategic food commodity for the West African region (Seck et al. 2013). Rice is the staple food of more than 750 million people in sub-Saharan Africa (USDA, 2016). Average annual rice consumption in sub-Saharan Africa (4\%) is increasing faster than rice production $(3.3 \%)$ (LARES, 2008). Longtime considered as a luxury food consumed during feast days; rice became part of eating habits of the populations of Benin. In Benin, 
while rice consumption is increasing, only $7 \%$ of the rice production potential (land and water resources) is used (JACQUES, 2008). In the country, rice ranks third regarding cereal production after maize and sorghum (ABEL, 2009) and is the second most crucial cereal regarding consumption after maize. Despite the progress realized in local rice production in subSaharan Africa after the food crisis of 2007-2008, rice demand has never been met; rice importation dependence is still around 50\% and local rice production represents only $60 \%$ of domestic consumption (Saito et al. 2015, USDA, 2016). The rapid increase in domestic rice production is a significant challenge for Sub-Saharan Africa (Secket al. 2012).

Given these situations and given that Benin has enormous potential for rice cultivation of which less than $8 \%$ is currently exploited, it is imperative to think of increasing the local supply of rice in order to satisfy local demand, reducing rice importation and increasing rice exportation.

This study aims to forecast rice production, rice consumption, rice importation, rice exportation and finally rice self-sufficiency over the next five years in Benin.

\section{Material and method}

\subsection{Methods of data collection}

The data used in this study were obtained from the official websites of the Ministry of Agriculture of Benin (MAEP) and Food and Agricultural Organization (FAO). For the time series data, we considered different periods: area, paddy rice and rice importation cover the period 1961-2016; rice exportation covers the period 1961-2015; milled rice and rice consumption cover the period 1961-2013. We took different periods for the time series because rice data of Benin are not available in the same period.

In this study, the self-sufficiency level is calculated by using the following formula. Self-sufficiency level $=($ Usable production/Domestic use $) \times 100$ (FAO, 2012b; Van Oort et al. 2015; Demirbaş et al. 2017).

\subsection{Methods used in data analysis}

Different models are used in data estimation. In agriculture domain, ARIMA model was used in many studies to forecast milled rice production (Suleman and Sarpong, 2012), to forecast rice area, production and productivity (Rahmanet al. 2016; Hemavathi and Prabakaran, 2018), to forecast the price of medium quality rice to anticipate price fluctuations (Ohyver and Pudjihastuti, 2018), to forecast maize production (Sharma et al., 2018). In this study, ARIMA model is also used for data estimation.

\section{ARIMA model}

Future estimation of a variable can be made only by using the variable itself without anyother variables.
These estimates are not based on a theoretical model. The movement of the variable in the past can be used to predict future movement. A linear time series models introduced by Box and

Jenkins (1970), are now widely used and accepted. According to them, the ARIMA model is

denoted by ARIMA ( $p, d, q)$ where ' $p$ ' is the order of the autoregressive process (AR); ' $d$ ' is the order of homogeneity i.e. the number of difference to make the series stationary; and ' $q$ ' the order of the moving average process (MA) (Box and Jenkins, 1970; Awajan et al., 2017).

The general form of the ARIMA (p, d, q) is

$Y_{t}=\varsigma+\beta_{1} Y_{t-1}+\beta_{1} Y_{t-2}+\ldots+\beta_{1} Y_{t-p}+\varepsilon_{t}+\theta_{1} \varepsilon_{t-1}$ $+\theta_{2} \varepsilon_{t-2}+\ldots+\theta_{q} \varepsilon_{t-q}$ (Kennedy, 2006:351).

Here, $\mathrm{Yt}$ gives the time series, $\varepsilon$ t error term, $\beta$ model estimator, $\varsigma$ time series average.

Before doing an analysis of time series, we plot the data by using standard plots and summary statistics to see the behavior of the data. The sample ACF and the PACF pattern were done to see whether given data is stationary in its level and variability. Apart from rice exportation and rice consumption variables, the other variables are non- stationary in level since they have not fluctuated around constant mean and variance. Then we took the first difference of the data values and we selected the stationary levels of the data (Table1). The selection criterion is the probability $(5 \%)$. To determine the orders $(\mathrm{p}, \mathrm{q})$ we referred to ACF and the PACF pattern. We estimated the parameters and fixed the fitted ARIMA model. Therefore, the fitted ARIMA model is the one that has more significant coefficients, less volatile, a higher Rsquared, a lower Akaike Criterion (AIC) and a Theil'sinequality coefficient less than 1 (Table2). The final step of the validity of the fitted model was based on the distribution of residuals and of residuals square to find out whether the residuals are a white noise or not and find out whether all the information contained in the series have been exploited or not.

\section{Test of forecast accuracy of the Box Jenkins method.}

Theil's U statistic measures the forecast accuracy (Theil, 1958). In this study, Theil's inequality coefficient is used to measure the predictive accuracy of models.

Theil Inequality Coefficient

$U=\frac{\sqrt{\frac{1}{n} \sum_{\mathrm{i}=1}^{\mathrm{n}}\left(\Delta \hat{\mathrm{Y}}_{\mathrm{i}}-\mathrm{Y}_{\mathrm{i}}\right)^{2}}}{\sqrt{\frac{1}{n} \sum_{i=0}^{n}\left(\Delta \mathrm{Y}_{\mathrm{i}}\right)^{2}}}$

$\Delta \mathrm{Y}_{\mathrm{i}}=$ actual change of variable

$\Delta \hat{\mathrm{Y}} \mathrm{i}=$ predicted change of variable

$\mathrm{n}=$ Number of observations

The coefficient $U$ is bounded between 0 and $1(0 \leq$ $\mathrm{U} \leq 1)$. Theil'sinequality coefficient shows the predictive accuracy of the model. This coefficient 
should be less than 1 (Vergil and Ozkan, 2007; Okur, 2009, Özer and İlkdoğan, 2013). The prediction of the model will not be accurate if the calculated value is greater than 1 . In that case, the model is not the most appropriate one. In This study, Theil'sinequality coefficient is used to select the most appropriate model for the estimation (Table2).

\subsection{Unit root test}

Augmented Dickey-Fuller test was carried out for the stability test. After the stationary studies of the series, only consumption and exportation series are stationary in level. Import, white rice production, paddy production and area series are stationary in first difference (Table 1).

\section{Results and Discussion}

Table1

The results of ADF unit root test.

\begin{tabular}{|c|c|c|c|c|c|c|c|c|c|c|}
\hline \multirow{2}{*}{ Variables } & \multicolumn{5}{|c|}{ Test atlevel } & \multicolumn{5}{|c|}{ First difference test } \\
\hline & Lag & Model & $\mathrm{ADF}$ & Critic & Processus & Lag & Model & $\mathrm{ADF}$ & Critic & Processus \\
\hline Cons_b & 8 & $\begin{array}{c}\text { Trend et } \\
\text { constante }\end{array}$ & $\begin{array}{c}- \\
5.26\end{array}$ & -5.34 & $\mathrm{I}(0)$ & & & & & \\
\hline Exp01 & 8 & $\begin{array}{l}\text { Trend et } \\
\text { constante }\end{array}$ & 5.26 & -5.34 & $\mathrm{I}(0)$ & & & & & \\
\hline Imp & 7 & $\begin{array}{l}\text { Trend et } \\
\text { constante }\end{array}$ & 4.43 & -4.85 & $\begin{array}{c}\text { Non } \\
\text { stationnaire }\end{array}$ & 0 & constante & 11.52 & -4.85 & I (1) \\
\hline PROB_b & 7 & Constante & 0.73 & -4.44 & $\begin{array}{c}\text { Non } \\
\text { stationnaire }\end{array}$ & 0 & $\begin{array}{l}\text { Trend et } \\
\text { constante }\end{array}$ & -7.25 & -4.85 & I (1) \\
\hline Prod_p & 5 & $\begin{array}{l}\text { Trend et } \\
\text { constante }\end{array}$ & $\begin{array}{c}- \\
2.62\end{array}$ & -4.65 & $\begin{array}{c}\text { Non } \\
\text { stationnaire }\end{array}$ & 0 & constante & -6.43 & -4.44 & I (1) \\
\hline Sup & 2 & $\begin{array}{l}\text { Trend et } \\
\text { constante }\end{array}$ & - & -4.85 & $\begin{array}{c}\text { Non } \\
\text { stationnaire }\end{array}$ & 7 & $\begin{array}{l}\text { Trend et } \\
\text { constante }\end{array}$ & -5.94 & -4.85 & $\mathrm{I}(1)$ \\
\hline
\end{tabular}

Tests are significant at $5 \%$.

Table2

Summary of models

\begin{tabular}{lccccc}
\hline Variables & $\begin{array}{c}\text { Order of } \\
\text { integration }\end{array}$ & Model & Adjusted model & $\begin{array}{c}\text { Theil'sinequality } \\
\text { coefficient }\end{array}$ & Probability \\
\hline Cons_b & I (0) & AR (1) & AR (1) AR (2) & 0.28 & 0.001 \\
Exp01 & I (0) & ARMA (1,1) & & 0.79 & 0.000018 \\
Imp & I (1) & ARIMA (1,1,1) & & 0.52 & 0.00061 \\
Prod_b & I (1) & ARIMA (3,1,3) & & 0.43 & 0.007 \\
Prod_p & I (1) & ARIMA (5, 1,3) & & 0.29 & 0.00015 \\
Sup & I (1) & ARIMA(1,1,12) & & 0.31 & 0.00016 \\
\hline
\end{tabular}

The Theil's inequality coefficients for all the models are less than 1. So, the selected models are good for the prediction. 


\subsection{Estimates of rice consumption}



Figure 1

Rice consumption ACF and PACF for stationary series.

The rice consumption series is an $\mathrm{I}(0)$. By observing the Figure1, the model to be estimated is AR (1) and its values are shown in the table3.

Table3

The values of AR(1) model

\begin{tabular}{lcccc}
\hline Model & Coefficient & Std. Error & t-Statistic & Probability \\
\hline AR $(1)$ & 0.995 & 0.027 & 36.609 & 0.000 \\
\hline
\end{tabular}

The residuals correlogram shows that there is unused information in the model like MA (3) and

Table4

The values of $\mathrm{R}(2), \mathrm{AR}(1)$ and MA(3) models

\begin{tabular}{lcc}
\hline & AR $(2)$ & AR (1) and MA (3) \\
\hline Significant coefficients $^{2}$ & 2 & 2 \\
Sigma $^{2}$ (volatility) & $5.52 * 10^{8}$ & $5.47 * 10^{8}$ \\
$\mathrm{R}^{2}$ adjusted & 0.98 & 0.98 \\
AIC & 23.21 & 23.22 \\
\hline
\end{tabular}

The most appropriate model is the one that has more significant coefficients, less volatile, a higher R-squared, and a lower Akaike Criterion (AIC). This model is the model AR (2). To validate this model, we analyzed the correlogram of residuals and residuals squared.

When one still observes the correlogram of the residuals squared, one notices that there is serial
AR (2). That's why we need to estimate the adjusted model and choose the most appropriate model.

autocorrelation. It must be corrected by integrating an AR (7) or MA (7). After estimation, it is the MA (7) that corrects it (Table4).

The correlogram of the residuals on this adjusted model shows that all the information is integrated into the model and the correlogram of the residuals squared shows that there is no more serial correlation. 
Forecast

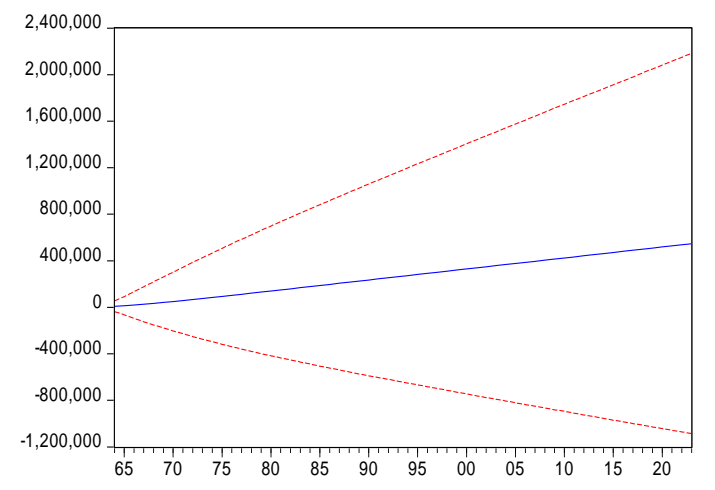

Figure2

Plot of rice consumption forecast.

Table4

Forecast values of rice consumption results

\begin{tabular}{|c|c|c|c|c|c|c|c|c|c|c|}
\hline Year & 2014 & 2015 & 2016 & 2017 & 2018 & 2019 & 2020 & 2021 & 2022 & 2023 \\
\hline $\begin{array}{l}\text { Forecast } \\
\text { (ton) }\end{array}$ & 538003.5 & 534626.6 & 529279.5 & 511713.1 & 506690.0 & 491890.5 & 476481.4 & 462716.0 & 450114.1 & 438388.4 \\
\hline
\end{tabular}

Rice consumption will decrease from 491890.5 tons in 2019 to 438388.4 tons in 2023 (Table5, Figure2).

\subsection{Estimates of rice exportation}

\begin{tabular}{|c|c|c|c|c|c|c|c|c|}
\hline \multicolumn{2}{|c|}{ Autocorrelation } & \multicolumn{2}{|c|}{ Partial Correlation } & \multicolumn{2}{|r|}{$A C$} & \multirow{2}{*}{$\frac{\text { PAC }}{0.368}$} & \multirow{2}{*}{$\frac{\text { Q-Stat }}{7.5869}$} & \multirow{2}{*}{ Prob } \\
\hline , & & & 马 & 1 & 0.368 & & & \\
\hline ' & 1 & & 1 & 2 & 0.119 & -0.018 & 8.4020 & 0.015 \\
\hline iE & i & & i & 3 & 0.105 & 0.078 & 9.0471 & 0.029 \\
\hline & I & & ' & 4 & 0.046 & -0.019 & 9.1749 & 0.057 \\
\hline & , & & ' & 5 & 0.017 & 0.002 & 9.1931 & 0.102 \\
\hline ; & ; & & i & 6 & -0.002 & -0.015 & 9.1933 & 0.163 \\
\hline ' & ' & & ' & 7 & -0.008 & -0.004 & 9.1 & 0.239 \\
\hline & I & & ' & 8 & -0.008 & -0.005 & 9.2014 & 0.326 \\
\hline ' & ' & & ' & 9 & -0.009 & -0.003 & 9.2067 & 0.418 \\
\hline ' & ' & & ' & 10 & -0.008 & -0.003 & 9.2115 & 0.512 \\
\hline & ' & & ' & 11 & -0.011 & -0.007 & 9.2207 & 0.602 \\
\hline i & i & & i & 12 & -0.008 & -0.001 & 9.2255 & 0.684 \\
\hline ' & ' & & ' & $1 \overline{3}$ & 0.004 & 0.010 & 9.2268 & 0.756 \\
\hline & ' & & . & 14 & 0.025 & 0.025 & 9.2722 & 0.813 \\
\hline ' & ' & & ' & 15 & -0.017 & -0.040 & 9.2946 & 0.862 \\
\hline , & , & & . & 16 & -0.015 & 0.002 & 9.3136 & 0.900 \\
\hline & ' & & ' & 17 & -0.014 & -0.013 & 9.3284 & 0.929 \\
\hline & ' & & & 18 & -0.019 & -0.008 & 9.3590 & 0.951 \\
\hline I & 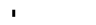 & & ' & 19 & -0.020 & -0.010 & 9.3939 & 0.966 \\
\hline 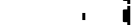 & I & & ' & 20 & -0.021 & -0.009 & 9.4333 & 0.977 \\
\hline & ' & & ' & 21 & -0.022 & -0.011 & 9.4786 & 0.985 \\
\hline ' & ' & & & 22 & -0.023 & -0.011 & 9.5298 & 0.990 \\
\hline ' & I & & ' & 23 & -0.024 & -0.011 & 9.5876 & 0.994 \\
\hline I & I & 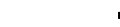 & ' & 24 & -0.025 & -0.012 & 9.6526 & 0.996 \\
\hline
\end{tabular}

Figure3

Rice exportation ACF and PACF for stationary series.

The Rice exportation series is an $\mathrm{I}(0)$. By observing the Figure3, the model to be estimated is

the ARMA model $(1,1)$ and the its values are shown in the table5

Table 5

The values of AR(1) and MA(1) models

\begin{tabular}{lcrcc}
\hline Model & Coefficient & Std. Error & t-Statistic & Probability \\
\hline AR(1) & 0.292 & 0.801 & 0.365 & 0.016 \\
MA(1) & 0.081 & 0.907 & 0.089 & 0.029 \\
\hline
\end{tabular}


Akouegnonhou and Demirbaş / Selcuk J Agr Food Sci, (2019) 33 (3), 204-214

\section{Forecast}

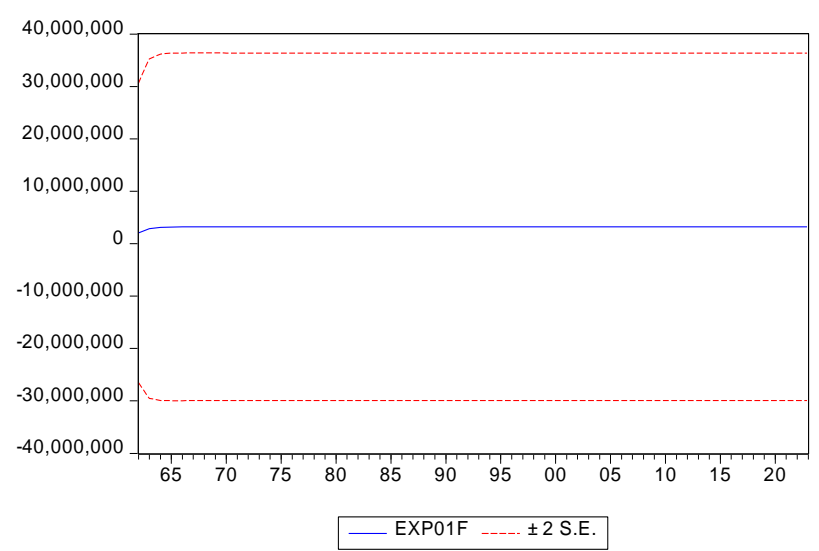

EXP01F

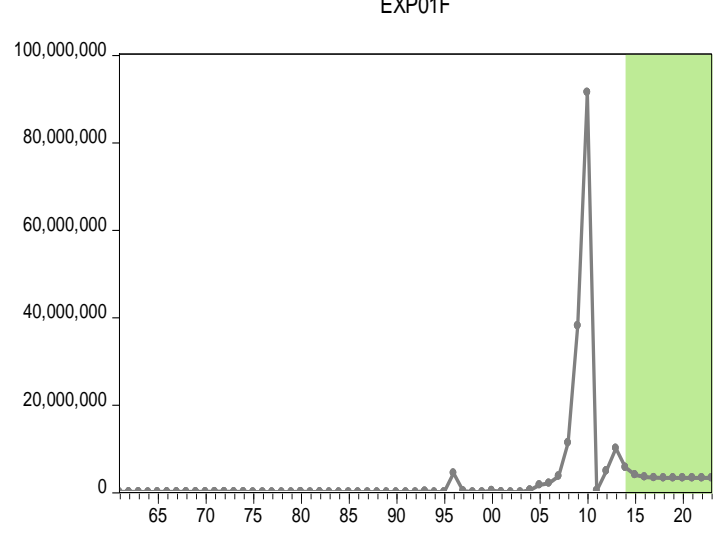

Figure4

Exportation forecast graphs

Table6

Forecast for rice exportation

\begin{tabular}{lcccccccc}
\hline Year & 2016 & 2017 & 2018 & 2019 & 2020 & 2021 & 2022 & 2023 \\
\hline $\begin{array}{l}\text { Forecast } \\
\text { (ton) }\end{array}$ & 3426473.63 & 3278216.33 & 3234802.85 & 3222090.29 & 3218367.73 & 3217277.67 & 3216958.47 & 3216865 \\
\hline
\end{tabular}

Rice Exportations will decrease slightly from

3222090.29 tons in 2019 to 3216865 tons in

2023(Table6, Figure4).

3.4.Estimates of rice importation

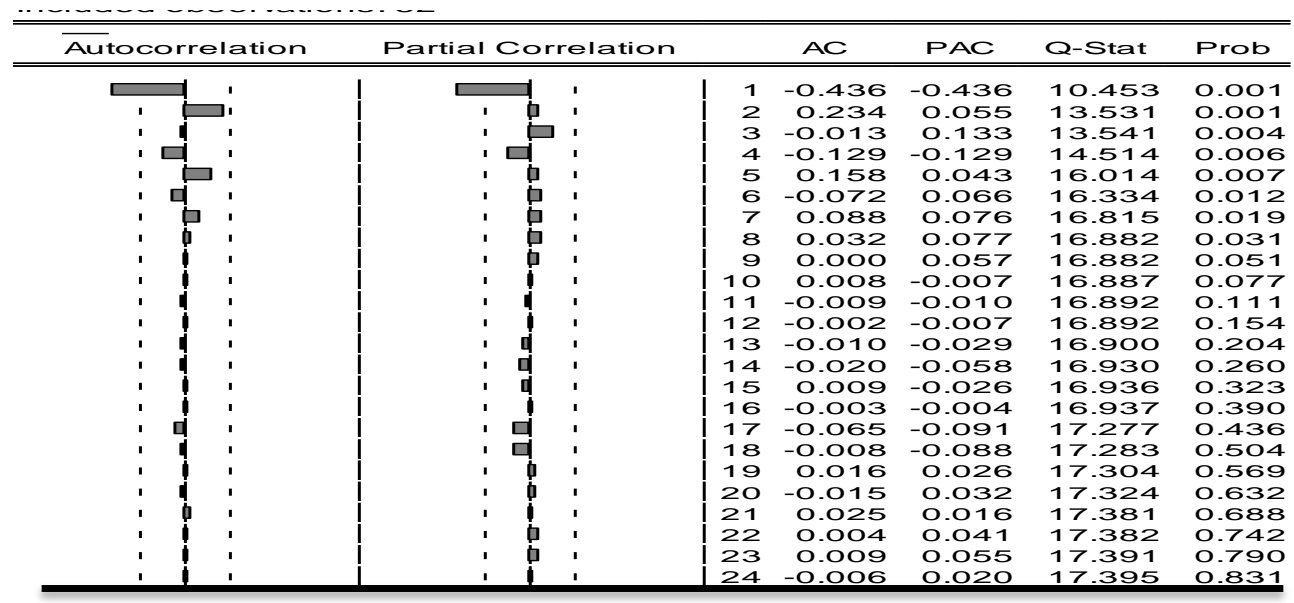

Figure5

Rice importation ACF and PACF for stationary series.

The series of import is an I(1). By observing the and the its values are shown in the table7.

Figure5, the model to be estimate is $\operatorname{ARIMA}(1,1,1)$

Table 7

The values of AR(1) and MA(1) models

\begin{tabular}{lcrcc}
\hline Model & Coefficient & Std. Error & t-Statistic & Probability \\
\hline AR(1) & -0.749 & 0.225 & -3.315 & 0.0018 \\
MA(1) & 0.251 & 0.494 & 0.507 & 0.0061 \\
\hline
\end{tabular}




\section{Forecast}

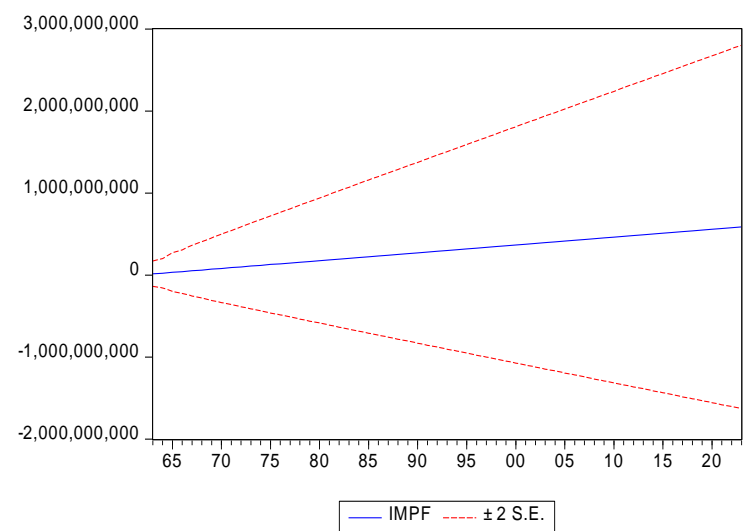

Figure6

Plots of importation forecast

Table8

Forecast for rice importation

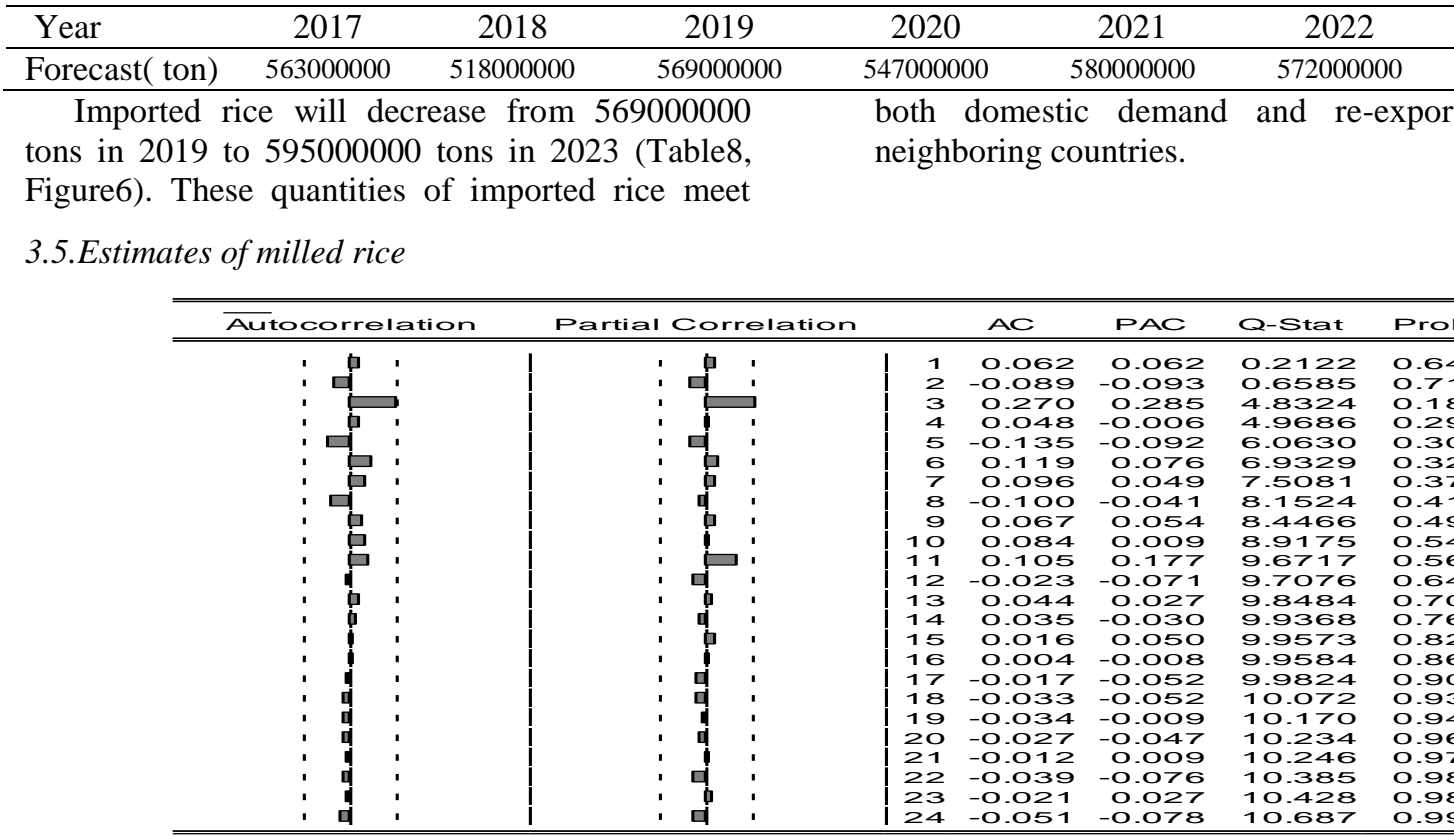

Figure7

Milled rice ACF and PACF for stationary series

The series of consumption is an I(1). By observing the Figure7 the model to be estimated is

Table9

The values of AR(3) and MA(3) models

\begin{tabular}{lcrcc}
\hline Model & Coefficient & Std. Error & t-Statistic & Probability \\
\hline AR(3) & 0.811 & 0.316 & 2.564 & 0.013 \\
MA(3) & 0.066 & 0.501 & 0.132 & 0.0084 \\
\hline
\end{tabular}

$\operatorname{ARIMA}(3,1,3)$ and the models values are shown in the table9.

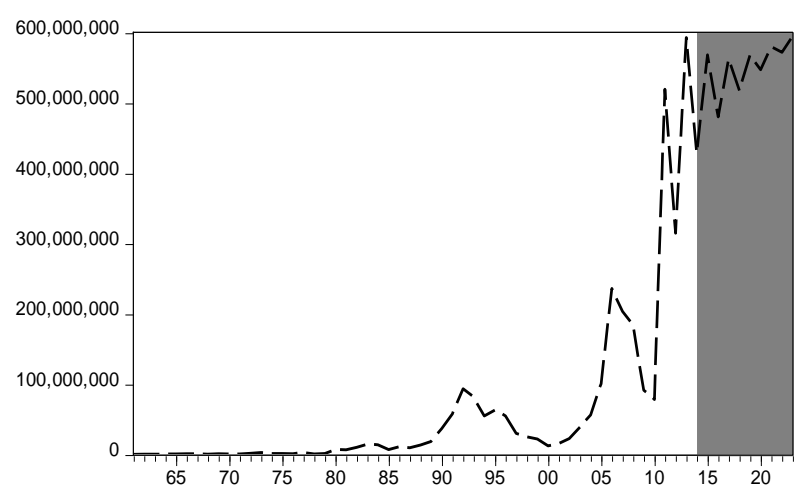

ns to 


\section{Forecast}

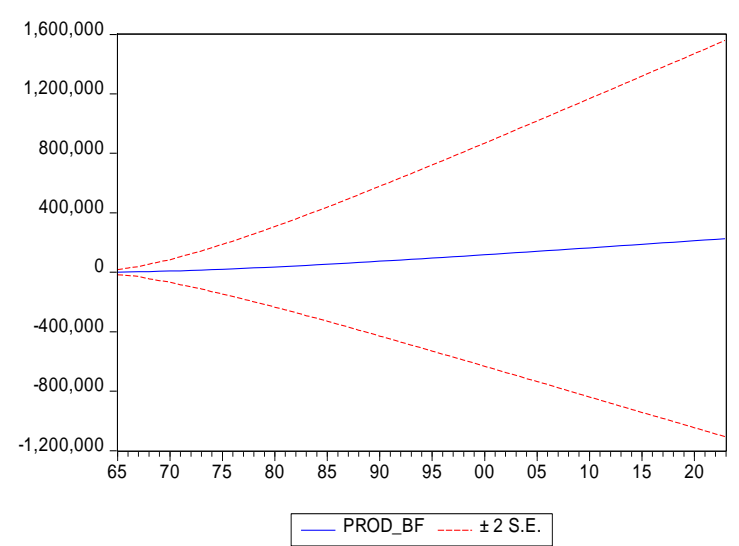

Figure8

Plot of milled rice forecast

Table10

Forecast for milled rice

\begin{tabular}{lcccccccccc}
\hline Year & 2014 & 2015 & 2016 & 2017 & 2018 & 2019 & 2020 & 2021 & 2022 & 2023 \\
\hline Forecast (ton) & 193056.2 & 193612 & 186993.7 & 232599.9 & 233974.2 & 229526.1 & 267462.9 & 269501.5 & 266814.8 & 298527.1 \\
\hline
\end{tabular}

Milled rice will increase from 229526.1 tons in 2019 to 298527.1 tons in 2023 (Table10, Figure8).

\subsection{Estimates of paddy rice production}

\begin{tabular}{|c|c|c|c|c|c|c|}
\hline elation & orrelation & & $A C$ & PAC & $Q-S t a t$ & Prob \\
\hline 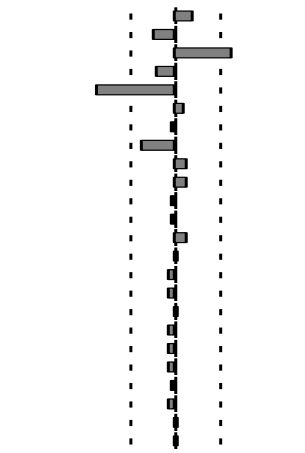 & : 包: & $\begin{array}{l}1 \\
2 \\
3 \\
4 \\
5 \\
6 \\
7 \\
8 \\
9 \\
10 \\
111 \\
12 \\
13 \\
14 \\
15 \\
16 \\
17 \\
18 \\
19 \\
20 \\
21 \\
22 \\
23 \\
24\end{array}$ & $\begin{array}{r}0.105 \\
-0.125 \\
0.342 \\
-0.101 \\
-0.474 \\
0.061 \\
-0.016 \\
-0.191 \\
0.068 \\
0.076 \\
-0.020 \\
-0.014 \\
0.076 \\
-0.007 \\
-0.036 \\
-0.038 \\
0.002 \\
-0.046 \\
-0.034 \\
-0.029 \\
-0.013 \\
-0.028 \\
0.002 \\
-0.006\end{array}$ & $\begin{array}{r}0.105 \\
-0.138 \\
0.383 \\
-0.269 \\
-0.371 \\
0.057 \\
-0.036 \\
0.144 \\
-0.110 \\
-0.127 \\
0.096 \\
-0.115 \\
0.154 \\
-0.101 \\
-0.016 \\
-0.058 \\
-0.047 \\
-0.077 \\
-0.065 \\
-0.067 \\
-0.039 \\
-0.055 \\
0.086 \\
-0.101\end{array}$ & $\begin{array}{l}0.6536 \\
1.5992 \\
8.7653 \\
9.3991 \\
23.730 \\
23.972 \\
23.988 \\
26.455 \\
26.774 \\
27.179 \\
27.208 \\
27.222 \\
27.653 \\
27.656 \\
27.759 \\
27.874 \\
27.874 \\
28.053 \\
28.157 \\
28.232 \\
28.248 \\
28.322 \\
28.322 \\
28.326\end{array}$ & $\begin{array}{l}0.419 \\
0.450 \\
0.033 \\
0.052 \\
0.000 \\
0.001 \\
0.001 \\
0.001 \\
0.002 \\
0.002 \\
0.004 \\
0.007 \\
0.010 \\
0.016 \\
0.023 \\
0.033 \\
0.046 \\
0.061 \\
0.080 \\
0.104 \\
0.133 \\
0.165 \\
0.204 \\
0.247\end{array}$ \\
\hline
\end{tabular}

Figure9

Paddy rice ACF and PACF for stationary series.

The series of paddy rice is an $\mathrm{I}(1)$. The analysis

the following competing models $(3,1,5)$; ARIMA of the ACF and PACF functions allows us to retain

Table11

Comparison of different ARIMA models with model fit statistics for paddy rice

\begin{tabular}{lcccc}
\hline & $\begin{array}{c}\text { ARIMA } \\
(3,1,5)\end{array}$ & $\begin{array}{c}\text { ARIMA } \\
(5,1,3)\end{array}$ & $\begin{array}{c}\text { ARIMA } \\
(3,1,3)\end{array}$ & $\begin{array}{c}\text { ARIMA } \\
(5,1,5)\end{array}$ \\
\hline Significant & 2 & 2 & 0 & 0 \\
coefficients & & $1.65 .10^{8}$ & $2.58 .10^{8}$ & $2.03 .10^{8}$ \\
Sigma $^{2}$ (volatility) & $1.74 .10^{8}$ & 0.4791 & 0.1840 & 0.35 \\
Adjusted R & 0.4504 & 21.97 & 22.37 & 22.16 \\
AIC & 22.01 & & & \\
\hline
\end{tabular}

The most appropriate model is one that has more significant coefficients, less volatility, a higher Rsquared, and a lower Akaike Criterion (AIC). ).
Based on the Table11, the model ARIMA $(5,1,3)$. was selected as the most appropriateon. 


\section{Forecast}

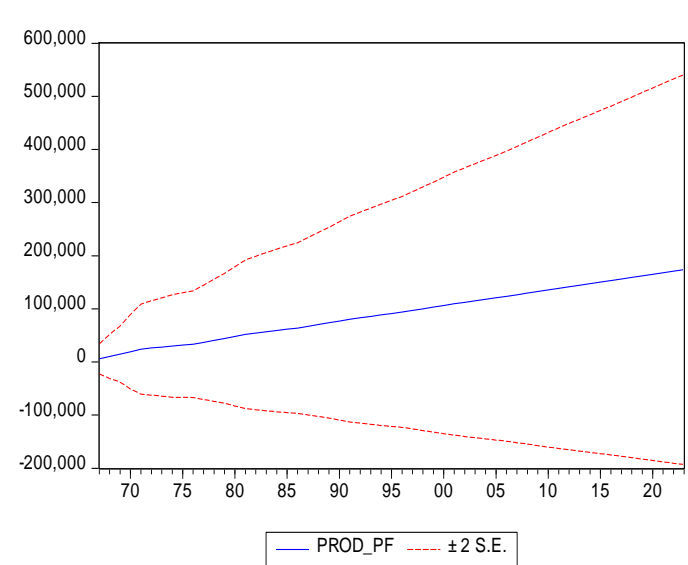

PROD_PF

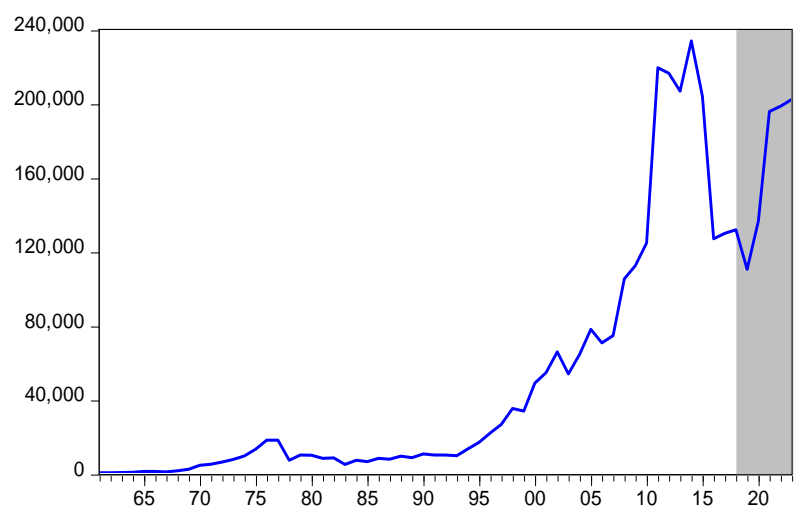

Figure 10

Plots of paddy forecast

Table12

Forecast for paddy rice

\begin{tabular}{lccccccc}
\hline Year & 2017 & 2018 & 2019 & 2020 & 2021 & 2022 & 2023 \\
\hline $\begin{array}{l}\text { Forecast } \\
\text { (ton) }\end{array}$ & 130189.8 & 132034.3 & 110682.8 & 136757.4 & 195994.9 & 198872.7 & 202584.1 \\
\hline
\end{tabular}

Paddy rice will increase from 110682.8 tons in 2019 to and to 202584.1 tons in 2023 (Table12, Figure10).

3.7.Estimates of area of rice production

\begin{tabular}{|c|c|c|c|c|c|c|}
\hline Autocorrelation & Partial Correlation & & $A C$ & PAC & Q-Stat & Prob \\
\hline 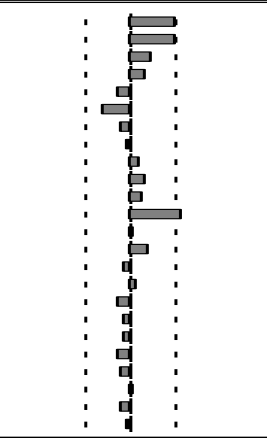 & : & $\begin{array}{l}11 \\
2 \\
3 \\
4 \\
5 \\
6 \\
7 \\
8 \\
9 \\
110 \\
112 \\
13 \\
134 \\
15 \\
16 \\
18 \\
18 \\
120 \\
21 \\
22 \\
23 \\
24\end{array}$ & $\begin{array}{r}0.279 \\
0.278 \\
0.116 \\
0.084 \\
-0.081 \\
-0.166 \\
-0.065 \\
0.0105 \\
0.055 \\
0.085 \\
0.074 \\
0.012 \\
0.1010 \\
-0.044 \\
0.029 \\
-0.068 \\
-0.036 \\
-0.034 \\
-0.068 \\
-0.011 \\
-0.059 \\
-0.009\end{array}$ & $\begin{array}{r}0.279 \\
0.219 \\
-0.006 \\
-0.0000 \\
-0.140 \\
-0.161 \\
0.059 \\
0.0991 \\
0.094 \\
0.063 \\
-0.039 \\
0.246 \\
-0.164 \\
0.020 \\
-0.050 \\
0.026 \\
0.012 \\
0.043 \\
-0.038 \\
-0.086 \\
-0.089 \\
-0.073 \\
-0.053 \\
\end{array}$ & $\begin{array}{l}4.4288 \\
8.9231 \\
9.7207 \\
10.151 \\
10.553 \\
12.281 \\
12.555 \\
12.573 \\
12.756 \\
13.256 \\
13.631 \\
20.205 \\
20.213 \\
20.983 \\
21.138 \\
21.203 \\
21.573 \\
21.686 \\
21.788 \\
22.1986 \\
22.546 \\
22.551 \\
22.888 \\
22.897\end{array}$ & $\begin{array}{l}\text { O.035 } \\
0.012 \\
0.021 \\
0.038 \\
0.0661 \\
0.056 \\
0.084 \\
0.127 \\
0.174 \\
0.210 \\
0.254 \\
0.063 \\
0.090 \\
0.102 \\
0.132 \\
0.1371 \\
0.202 \\
0.246 \\
0.295 \\
0.330 \\
0.369 \\
0.427 \\
0.467 \\
0.526\end{array}$ \\
\hline
\end{tabular}

Figure 11

Area ACF and PACF for stationary series

The series of area is an I(1). The analysis of the $\mathrm{ACF}$ and PACF functions allows us to retain the following competing models: ARIMA $(1,1,12)$;

ARIMA (12, 1, 1); ARIMA $(12,1,12)$; ARIMA $(1,1,1)$.

Table13

The values of ARIMA $(1,1,12)$; ARIMA $(12,1,1)$; ARIMA $(12,1,12)$; ARIMA $(1,1,1)$

\begin{tabular}{lcccc}
\hline & $\begin{array}{c}\text { ARIMA } \\
(1,1,12)\end{array}$ & $\begin{array}{c}\text { ARIMA } \\
(12,1,1)\end{array}$ & ARIMA $(12,1,12)$ & $\begin{array}{c}\text { ARIMA } \\
(1,1,1)\end{array}$ \\
\hline Significant & 1 & 2 & 1 & 1 \\
coefficients & 4583815 & 6257622 & 4707474 & 8620418 \\
Sigma2 (volatility) & 0.5030 & 0.3215 & 0.48 & 0.06 \\
Adjusted R2 & 18.70 & 18.75 & 18.77 & 18.95 \\
AIC & . & & & 1 \\
\hline
\end{tabular}

The most appropriate model is one that has more significant coefficients, less volatility, a higher R-squared, and a lower Akaike Criterion on the Table13, the ARIMA model $(1,1,12)$ was (AIC). Based 
Forecast

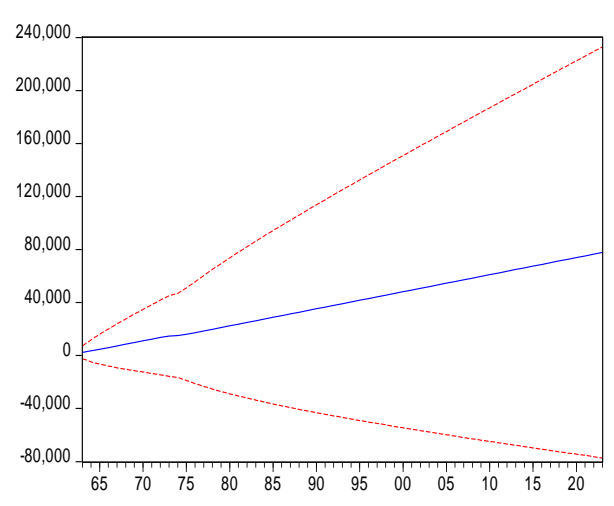

Figure12

Area forecast graphs

Table14

Forecast for area

\begin{tabular}{lccccccc}
\hline Year & 2017 & 2018 & 2019 & 2020 & 2021 & 2022 & 2023 \\
\hline $\begin{array}{l}\text { Forecast } \\
\text { (ha) }\end{array}$ & 69394.72 & 67459.67 & 67317.95 & 71249.31 & 76254.26 & 80540.58 & 87708.02 \\
\hline
\end{tabular}

The cultivated area will increase from 67317.95 ha in 2019 to 87708.02 ha in 2023 (Table14, Figure12).

Table15

Self-sufficiency rate (2019-2023)

\begin{tabular}{lccccc}
\hline Year & 2019 & 2020 & 2021 & 2022 & 2023 \\
\hline Milled rice (ton) & 229526.1 & 267462.9 & 269501.5 & 266814.8 & 298527.1 \\
Rice consumption (ton) & 491890.5 & 476481.4 & 462716 & 450114.1 & 438388.4 \\
Self-sufficiency (\%) & 47 & 56 & 58 & 59 & 68 \\
\hline
\end{tabular}

Based on Table15, one observes that the rate of self-sufficiency will increase and will reach its peak $(68 \%)$ in 2023. It can be concluded that Benin will continue importing large quantities of rice to meet domestic demand and fill the gap of about $32 \%$ of the self-sufficiency rate remaining during the next five years.

According to estimates of theMinistry of Agriculture of Benin, Benin was expected to reach its self-sufficiency level in rice production since 2013 through domestic production (MAEP, 2010). However, this goal could not be achieved due to inadequate agricultural policies. Right now, the self-sufficiency level in rice production is around $60 \%$ and this, because of insufficient domestic production.

\section{Conclusion and Suggestions}

This study aims to give an overall idea of the rice sector in Benin and to forecast the variables of rice over the next five years by using the model. As a result, the self-sufficiency level will not be reached during the next five years. It will be about $68 \%$. The fact is that annual rice consumption is increasing faster than annual rice production in Benin and in sub-Saharan Africa. Between 2010 and 2035, rice demand in sub-Saharan Africa is expected to increase by $130 \%$ (Secket al. 2012). Rice importations are likely to lose foreign exchange reserves and increase poverty and food insecurity. The rapid increase in local rice production is a significant challenge for subSaharan Africa (Catherine and Chapoto, 2017). To meet local consumption growth, rice production policies need to be redirected and revised. Because importation dependence can seriously affect food security and political stability, as demonstrated during the 2007-2008 food crisis (Berazneva and Lee, 2013). Sustainable food security cannot be based on importations, and it should be found on the development of domestic production for adequate protection against fluctuations in world prices (Larochea and Postolle, 2013).

\section{References}

Abel G J (2009). Etude sur le développement des filières riz et maraîchage au Bénin. CTB ; pp.77.

Aho N, Kossou D (1997). Précis d'Agriculture Tropicale : Bases et Eléments d'Application. Edition du Flamboyant :Cotonou.

Awajan AM, Ismail MT, Al Wadi S (2017). A hybrid EMD-MA for forecasting stock market index. Italian Journal of Pure \& Applied Mathematics, 38(1), 1-20. 
Beegle K, Christiaensen L, Dabalen A, Gaddis I (2016). Poverty in a Rising Africa. Washington, DC: World Bank. (C) World Bank. https://openknowledge.worldbank.org/handle/10986/ 22575 License: CC BY 3.0 IGO.

Berazneva, Lee (2013). Explaining the African food riots of 2007-2008: An empirical analysis. Food Policy, $39,28-39$.

Box GEP, Jenkins GM (1970). Time series analysis: Forecasting and control, San Francisco: Holden-Day.

Catherine C (2017). Limits to Green Revolution in rice in Africa: Thecase of Ghana. pp: 1-18.

Christiaensen L (2017). A synthesis. February 2017, Food Policy 67, 1-11.

Christiaensen L, Demery L, Kuhl J (2011).The (evolving) role of agriculture in poverty reduction--An empirical perspective. Journal of Development Economics, Elsevier, vol. 96-2 (2011), pp 239-254.

DavisB, Di Giuseppe S, Zezza A (2017). Are African Households (Not) leaving agriculture? Patterns of households' income sources in rural Sub-Saharan Africa. Food Policy, 67 (2017), pp. 153-174

Demirbaş N, Niyaz ÖC, Daysal H (2017).Evaluation of Self-Sufficiency in Lentil Production in Turkey.Journal of Agricultural Faculty of Gaziosmanpasa University (JAFAG), (2017) 34 (3), 282-291.

FAO (2012a).Cadre de programmation pays (2012-2015).

FAO (2012b). FAO Statistical Yearbook 2012, WorldFoodand Agriculture http://www.fao.org/(Accessed to web: 5 March 2019 at $1: 21)$.

Fofana I, Goundan A, Domgho LVM (2014).Impact simulation of ECOWAS rice self sufficiency policy, IFPRI DiscussionPaper 1405. Washington, DC: International Food Policy Research Institute,http://ebrary.ifpri.org/cdm/ref/collection/p15 738 coll2/id/128894.

Hemavathi M, Prabakaran K (2018).ARIMA Model for Forecasting of Area, Production and Productivity of Rice and Its Growth Status in Thanjavur District of Tamil Nadu, India.Int.J.Curr.Microbiol.App.Sci. 7(02): $\quad$ 149156.doi:https://doi.org/10.20546/ijcmas.2018.702.019

Jacques AZ (2008). Etude économétrique de l'offre du riz local au Bénin à partir des données transversales; $87 \mathrm{p}$.

Kennedy P (2006). Ekonometrikilavuzu, (çevirenSarımeşeli M veAçıkgöz Ş.), Gazikitapevi, 5.bask1, Ankara, 745sayfa.

LARES (2008). Analyse des politiques et stratégies mises en œuvre par l'état dans la filière riz depuis 2008; 22p.

Laroche DP (2013). Food sovereignty and agricultural trade policy commitments: How much leeway do west African nations have?.Food Policy, 38, 115125.

MAEP (2007). Analyse de la rentabilité économique de la chaine de valeur ajoutée riz. Cotonou, Bénin.

MAEP (2010). Diagnostic du secteur agricole de pays: dépenses publiques, Octobre 2010.
Ohyver M, Pudjihastuti H (2018).Arima Model for Forecasting the Price of Medium Quality Rice to Anticipate Price Fluctuations. Procedia Computer Science 135 (2018) 707-711

Okur, $\mathrm{S}$

(2009). "ParametrikVeParametrikOlmayanBasitDoğrusalReg resyonAnalizYontemlerininKarşılaştırmalıOlarakİnce lenmesi"

YuksekLisansTezi,CukurovaUniversitesi,Adana

Özer, O O and İlkdoğan U (2013). Box-Jenkins Modeli Yardımıyla Dünya Pamuk Fiyatının Tahmini. JOTAF/Tekirdağ ZiraatFakültesiDergisi 10.2 (2013): 13-20.

PNUD-IDH (2011). Rapport sur le développement humain2011.http://hdr.undp.org/sites/default/files/hdr 2011_fr_complete.pdf(accessed 30June 2018, 10:12).

Rahman NMF, Hasan MM, Hossain MI, Baten MA, Hosen S, Ali MA, Kabir MS (2016). Forecasting Aus Rice Area and Production in Bangladesh using BoxJenkins Approach.

Saito K, Dieng I, Toure AA, Somado EA, Wopereis MCS (2015). Rice yield growth analysis for 24 African countries over 1960- 2012. Global Food Security, 5, 62-69.

Seck PA, Diagne A, Mohanty S, Wopereis MCS (2012). Crops that feed the world 7: rice. Food Security 4, 724.

Seck PA, Toure' AA, Coulibaly JY, Diagne A, Wopereis MCS (2013). Africa's rice economy before and after the 2008 rice crisis. In M. C. S. Wopereis, D. E. Johnson, N. Ahmadi, E. Tollens, \& A. Jalloh (Eds.), Realizing Africa's rice promise (pp. 24-34). Wallingford: CABI Publishing.

Sharma PK, Dwivedi S, Ali L, Arora RK (2018). Forecasting Maize Production in India using ARIMA Model. Agro Economist - An International Journal. AE: 5(1): 01-06, June 2018. DOI: 10.30954/23948159.01.2018.1.

Suleman N, Sarpong S (2012). Forecasting Milled Rice Production in Ghana Using Box-Jenkins Approach. International Journal of Agricultural Management \& Development, 2(2): 79-84, June, 2012.

Theil H (1958), Economic Forecasts and Policy. Amsterdam: North Holland. pp 31-42.

Thirtle C, Lin L, Piesse J (2003).TheImpact of ResearchLed Agricultural Productivity Growth on Poverty Reduction in Africa, Asia and Latin America. World Development, 31(12), 1959-1975. doi: 10.1016/ j.worlddev.2003.07.001.

USDA ( 2016). PSD Online home Custom query. 〈http://apps.fas.usda.gov/psdonline/.

Van Oort PAJ, Saito K, Tanaka A, Amovin-Assagba E, VanBussel LGJ, van Wart J, de Groot $\mathrm{H}$, van Ittersum MK, Cassman KG, Wopereis M C S (2015). Assessment of rice self-sufficiency in 2025 in eight African countries.

Vergil H and Ozkan F (2007). "Döviz Kurları Öngörüsünde Parasal Model ve Arima Modelleri”, Kocaeli Üniversitesi Sosyal Bilimler Enstitüsü Dergisi 13(1): 211[231. 